\title{
Early and unexpectedly severe start of influenza epidemic in the Czech Republic during influenza season 2012-13
}

J Kyncl (jkyncl@szu.cz)1,2, M Havlickova3 ${ }^{3}$ A Nagy³, H Jirincova3, I Piskova4

1. Department of Infectious Diseases Epidemiology, National Institute of Public Health, Prague, Czech Republic

2. Department of Epidemiology, Third Faculty of Medicine, Charles University in Prague, Czech Republic

3. National Reference Laboratory for Influenza, National Institute of Public Health, Prague, Czech Republic

4. Epidemiology Division, Department of Public Health Protection, Ministry of Health of the Czech Republic, Prague, Czech Republic

Kyncl J, Havlickova M, Nagy A, Jirincova H, Piskova I. Early and unexpectedly severe start of influenza epidemic in the Czech Republic during influenza season 201213. Euro Surveill. 2013;18(6):pii=20396. Available online: http://www.eurosurveillance.org/ViewArticle.aspx?Articleld=20396

Article published on 7 February 2013

A sudden increase in severe influenza has been registered in the Czech Republic since the end of $\mathbf{2 0 1 2}$, with 264 cases requiring intensive care, including 51 deaths. Most patients had at least one risk factor. Severe influenza in patients with obesity, smoking and/or haematological disorders including haematological cancers was more frequent than in the prepandemic period. The seasonal influenza vaccination status of the cases indicates indirect efficiency of the current vaccine in preventing severe influenza.

Influenza virus activity in Europe is detected each season, yet the precise timing and magnitude of this activity remain highly unpredictable. There was increased media attention regarding the re-occurrence of severe influenza $A\left(\mathrm{H}_{1} \mathrm{~N}_{1}\right)$ pdmog cases at the beginning of 2013 in the Czech Republic. This led to a higher demand of antiviral drugs. In order to clarify the current influenza situation, we provide here representative data from the case-based reports of severe influenza cases and combine them with the data received from routine surveillance.

\section{Influenza surveillance in the Czech \\ Republic}

Epidemiological and virological surveillance of influenza and other viral acute respiratory infections (ARI) is well established in the Czech Republic (population: 10.5 million) [1]. The surveillance system is active throughout the year and uses the European Union case definition for influenza [2]. Data are collected weekly and analysed at national level. The information is provided to the European Centre for Disease Prevention and Control (ECDC) and the World Health Organization (WHO), where it is analysed together with the data from other countries of the European Union and the WHO European Region, respectively $[3,4]$. There is no routine reporting of severe acute respiratory infection (SARI) from hospitals. Nevertheless, due to the occurrence of increased numbers of severe influenza cases during the pandemic in 2009, the Regional Public Health Authorities started, on request of the Ministry of Health of the Czech Republic to provide case-based information about hospitalised patients with influenza illness who require treatment at intensive or resuscitation care units.

To gain insight into the genetic characteristics of the influenza A viruses circulating in the Czech Republic, the National Influenza Reference Laboratory in Prague sequences the full coding region of the genome from selected isolates or positive clinical specimens and subsequently performs phylogenetic analysis of representative $A\left(\mathrm{H}_{1} \mathrm{~N}_{1}\right)$ pdmog influenza virus strains.

\section{Influenza season 2012/13}

Since mid-November 2012, the incidence of ARI and influenza-like illness (ILI) has been increasing in all monitored age groups $(0-5,6-14,15-24,25-59$, $\geq 60$ years and total population). There was an artificial decrease in reporting during the Christmas and New Year holidays that is seen every year. Since the beginning of January 2013, the reported ARI and ILI rates have not been unusual, and the influenza epidemic threshold of $1,600 \mathrm{ARI}$ cases per 100,000 population

\section{FIGURE 1}

Weekly morbidity from acute respiratory infection and influenza-like illness, Czech Republic, influenza season 2012/13

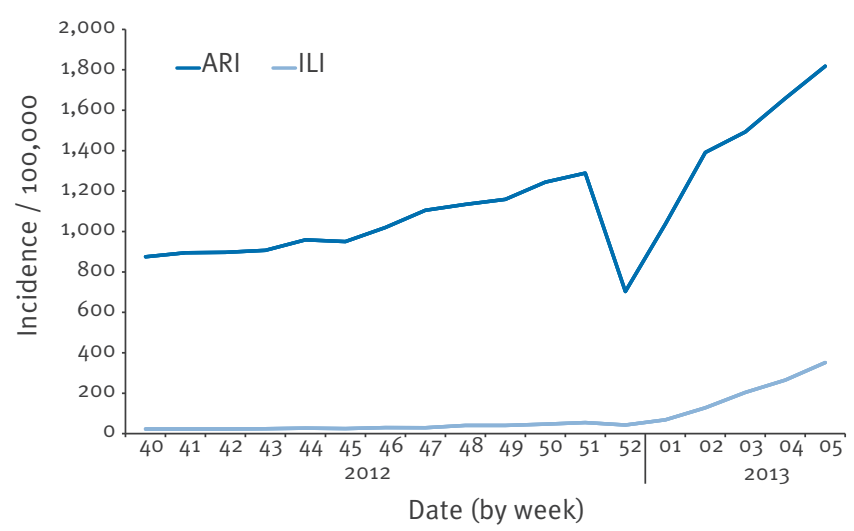

Rates per 100,000 population; data up to 1 February 2013. 
per week was reached as late as during week 4 of 2013 (week ending 25 January 2013) (Figure 1).

Nevertheless, two other indicators signalised significant influenza activity in the Czech Republic. Firstly, the absolute numbers as well as the percentage of influenza-positive samples among the tested specimens (sentinel sampling consists of two swabs, one child and one adult, collected per week from each of the 14 regions in the (zech Republic) has been considerably higher after week 51, 2012 (Table 1).

Secondly, hospital surveillance has noted a clear increase of very severe influenza illness since the beginning of the year 2013, compared to non-epidemic period. By 1 February 2013, a total of 264 hospitalised patients (159 male and 105 female) with severe influenza illness that required treatment at intensive or resuscitation care units (ICU) have been reported to public health authorities (Table 2). Among those were 51 deaths (34 men and 17 women).

Of the 264 ICU patients, 174 (66\%) were positive for influenza $A\left(\mathrm{H}_{1} \mathrm{~N}_{1}\right)$ pdmog virus, 76 (29\%) were positive for influenza $A$ (unknown sub-type), six were positive for influenza $A\left(\mathrm{H}_{3} \mathrm{~N}_{2}\right)$ virus, one for influenza $B$ virus, and seven cases remained unconfirmed by virology (determined by clinical diagnosis only). The virological results for influenza ICU patients were similar to the data from combined sentinel and non-sentinel surveillance.

The mean age of the influenza ICU patients was 56 years (min: one month; max: 92 years; median: 59 years). The mean age of the fatal influenza ICU cases was 64 years (min: 27 years; max: 92 years; median: 67 years). The main risk factors included: obesity with body mass index above 30 (79/264), smoking (65/264), chronic cardiovascular (77/264), respiratory (46/264) or haematological illness $(21 / 264)$, often in combination. Only seven patients were vaccinated against seasonal influenza during autumn 2012.

Phylogenetic analysis of the haemagglutinin (HA) gene of the first three strains in the $2012 / 13$ season, representing the influenza $A\left(\mathrm{H}_{1} \mathrm{~N}_{1}\right)$ pdmog viruses currently circulating the Czech Republic, indicate that they cluster within the $\mathrm{H}_{1} \mathrm{~N}_{1}$ pdmog group 6 . This group, along with H1N1pdmog group 7, represents the currently predominating phylogenetic lineages of this influenza virus strain in Europe (Figure 2; Table 3). Comparing our HA sequences with the $A / C$ alifornia/7/2009( $\left.\mathrm{H}_{1} \mathrm{~N}_{1}\right)$ strain revealed up to $12 / 549$ amino acid changes (A/Czech Republic/140/2012( $\left.\mathrm{H}_{1} \mathrm{~N}_{1}\right) ; 97.8 \%$ identity), three of which were localised within the known antigenic sites (in $\mathrm{H}_{3}$ numbering): $\mathrm{Ca} 2\left(\mathrm{H}_{141} \mathrm{R}\right), \mathrm{Sb}\left(\mathrm{S}_{188 \mathrm{~T}}\right)$ and $\mathrm{Ca} 1$ (S206T).

\section{Discussion and conclusions}

Influenza $\mathrm{A}\left(\mathrm{H}_{1} \mathrm{~N}_{1}\right) p d m o 9$ and unsubtyped influenza $A$ viruses were found in almost all cases of influenza ICU patients. Since the $A\left(\mathrm{H}_{1} \mathrm{~N}_{1}\right)$ pdmog virus was the predominant strain we suppose that the majority of unsubtyped influenza $A$ viruses also belonged to this subtype. The majority of deaths were linked primarily to rapidly developing respiratory failure as already described [5]. In particular, progressive pneumonitis caused by $A\left(\mathrm{H}_{1} \mathrm{~N}_{1}\right)$ pdmog virus is difficult to explain since the virus is neither shown to have markedly increased virulence over other seasonal influenza viruses, nor it is a particularly strong cytokine inducer in vitro [6]. The potential for increased pathogenicity could be a result of the combination of other genetic markers [7].

The current influenza situation in the Czech Republic is not exceptional as such. It is relatively similar to the season $2010 / 11$ when the influenza $A\left(\mathrm{H}_{1} \mathrm{~N}_{1}\right)$ pdmog virus dominated the epidemic. However, other European

\section{TABLE 2}

Number of severe influenza patients at intensive care units and deaths by week, Czech Republic, 22 December 2012-1 February $2013(n=264)$

\begin{tabular}{|l|c|c|}
\hline & Number of new cases & Of which deaths \\
\hline week 52, 2012 & 12 & 3 \\
\hline week 1, 2013 & 28 & 3 \\
\hline week 2, 2013 & 40 & 5 \\
\hline week 3, 2013 & 60 & 13 \\
\hline week 4, 2013 & 56 & 16 \\
\hline week 5, 2013 & 68 & 11 \\
\hline Total & $\mathbf{2 6 4}$ & $\mathbf{5 1}$ \\
\hline
\end{tabular}

\section{TABLE 1}

Sentinel and non-sentinel influenza virus detections, Czech Republic, influenza season 2012/13 (n=994)

\begin{tabular}{|c|c|c|c|c|c|c|c|c|c|c|c|c|c|c|c|c|c|}
\hline Week & 40 & 41 & 42 & 43 & 44 & 45 & 46 & 47 & 48 & 49 & 50 & 51 & 52 & 1 & 2 & 3 & 4 \\
\hline Influenza A & & 1 & & & & 3 & 1 & 1 & 2 & & 5 & 16 & 35 & 59 & 61 & 117 & 129 \\
\hline Influenza A(H1N1)pdmo9 & & & & & & & 2 & & & 1 & 5 & 10 & 10 & 67 & 133 & 95 & 164 \\
\hline Influenza $\mathrm{A}\left(\mathrm{H}_{3} \mathrm{~N}_{2}\right)$ & & 1 & 1 & & & & & & & & & 4 & 3 & & 12 & 10 & 16 \\
\hline Influenza B & & 1 & & 2 & & & 1 & & & & 1 & 2 & 1 & 3 & 6 & 5 & 8 \\
\hline Total influenza-positive & $\mathbf{0}$ & 3 & 1 & 2 & $\mathbf{0}$ & 3 & 4 & 1 & 2 & 1 & 11 & 32 & 49 & 129 & 212 & 227 & 317 \\
\hline Samples tested & 15 & 32 & 37 & 40 & 40 & 37 & 35 & 33 & 61 & 58 & 81 & 82 & 75 & 260 & 529 & 681 & 697 \\
\hline Positivity in \% & 0 & 9 & 3 & 5 & 0 & 8 & 11 & 3 & 3 & 2 & 14 & 39 & 65 & 50 & 40 & 33 & 45 \\
\hline
\end{tabular}


countries do not report such high numbers of severe influenza this year $[3,4]$. So far during this season, only 14 fatalities have been reported from EU countries in which hospital surveillance of severe influenza disease is established, 12 of these occurred in France [3]. With regards to circulation of influenza viruses in Europe, the situation is varied. For example, influenza $B$ virus is dominant mainly in the United Kingdom (UK), influenza $A\left(\mathrm{H}_{3} \mathrm{~N}_{2}\right)$ in Denmark and $\mathrm{A}\left(\mathrm{H}_{1} \mathrm{~N}_{1}\right)$ pdmo9 in Austria, Lithuania and Norway [3]. This report may serve as an alert that a sudden increase in severe influenza cases may soon be seen also in other, especially Eastern European, countries this season.
The observations presented here prompted us to build up the following hypothesis: the proportion of people vaccinated against influenza in the Czech Republic is small, only approx. $5 \%$ of the whole population. As this year's seasonal vaccine is matching the circulating viruses well, which resulted in a vaccine effectiveness of $62 \%$ in the United States [8], the proportion of people protected against influenza in other countries should be higher than in the Czech Republic, especially in Western Europe where the influenza epidemic started earlier.

In addition, we have to consider that the effectiveness of the trivalent vaccine may well be different for the different components. If the virus mix circulating in one country was considerably different from what is

\section{FIGURE 2}

Phylogenetic tree of influenza $\mathrm{A}(\mathrm{H} 1 \mathrm{~N} 1)$ haemagglutinin gene

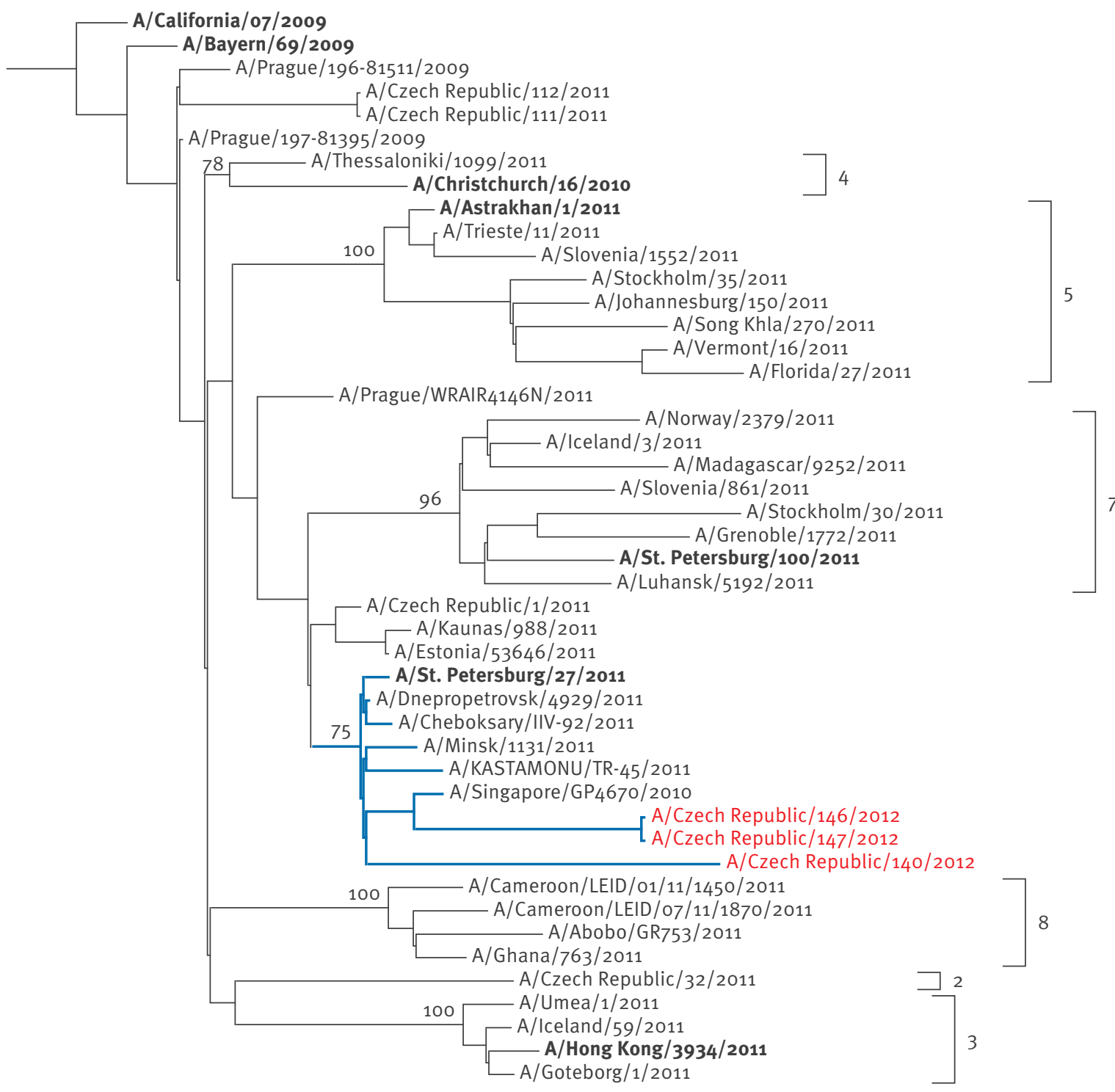


TABLE 3

Origin of the haemagglutinin sequences of pandemic influenza $\mathrm{A}(\mathrm{H} 1 \mathrm{N1})$ isolates included in the phylogenetic analysis

\begin{tabular}{|c|c|c|c|c|}
\hline \multirow{2}{*}{ Isolate name } & \multirow{2}{*}{ Collection date } & \multicolumn{2}{|c|}{ Isolate ID } & \multirow{2}{*}{ Originating laboratory } \\
\hline & & IVR & GISAID & \\
\hline A/Prague/197-81395/2009(H1N1) & 2009-06-27 & GU290047 & & \multirow{9}{*}{$\begin{array}{l}\text { National Institute of Public Health, Prague, Czech } \\
\text { Republic }\end{array}$} \\
\hline A/Prague/196-81511/2009(H1N1) & 2009-07-15 & GU290055 & & \\
\hline A/Czech Republic/32/2011(H1N1) & 2011-01-18 & & EPI_ISL_90718 & \\
\hline A/Czech Republic/1/2011(H1N1) & 2011-01-25 & JF682629 & & \\
\hline A/Czech Republic/111/2011(H1N1) & $2011-10-25$ & JQ693484 & & \\
\hline A/Czech Republic/112/2011(H1N1) & $2011-10-25$ & JQ693492 & & \\
\hline A/Czech Republic/140/2012(H1N1) & $2012-11-16$ & & EPI_ISL_133958 & \\
\hline A/Czech Republic/146/2012(H1N1) & $2012-12-27$ & & EPI_ISL_133959 & \\
\hline A/Czech Republic/147/2012(H1N1) & $2012-12-24$ & & EPI_ISL_133960 & \\
\hline A/Prague/WRAIR4146N/2011(H1N1) & 2011-01-18 & CY098004 & & $\begin{array}{l}\text { Walter Reed Army Institute of Research, Maryland, } \\
\text { United States }\end{array}$ \\
\hline A/California/07/2009(H1N1) & $\begin{array}{c}2009 \text { (month and } \\
\text { day unknown) }\end{array}$ & $\mathrm{CY}_{121680}$ & & $\begin{array}{l}\text { New York Medical College/NCBI, NIH, Bethesda, United } \\
\text { States }\end{array}$ \\
\hline A/Thessaloniki/1099/2011(H1N1) & 2011-03-08 & & EPI_ISL_90764 & Institut Pasteur Hellenique, Athens, Greece \\
\hline A/Bayern/69/2009( $\left.\mathrm{H}_{1} \mathrm{~N}_{1}\right)$ & $\begin{array}{c}2009 \text { (month and } \\
\text { day unknown) }\end{array}$ & & EPI_ISL_73686 & Robert Koch-Institute, Berlin, Germany \\
\hline A/Cheboksary/IIV-92/2011( $\left.\mathrm{H}_{1} \mathrm{~N}_{1}\right)$ & $2011-02-22$ & JN704791 & & $\begin{array}{l}\text { The D.I.Ivanovsky Institute of Virology, Moscow, } \\
\text { Russian Federation }\end{array}$ \\
\hline A/St. Petersburg/27/2011(H1N1) & 2011-02-14 & & EPI_ISL_90760 & \multirow{2}{*}{$\begin{array}{l}\text { WHO National Influenza Centre, St. Petersburg, } \\
\text { Russian Federation }\end{array}$} \\
\hline A/Astrakhan/1/2011(H1N1) & $2011-02-28$ & & EPI_ISL_90787 & \\
\hline A/St. Petersburg/100/2011( $\left.\mathrm{H}_{1} \mathrm{~N}_{1}\right)$ & $2011-03-14$ & & EPI_ISL_90954 & $\begin{array}{l}\text { Russian Academy of Medical Sciences, St. Petersburg, } \\
\text { Russian Federation }\end{array}$ \\
\hline A/Dnepropetrovsk/4929/2011(H1N1) & 2011-03-10 & & EPI_ISL_99894 & \multirow{2}{*}{$\begin{array}{l}\text { Institute of Epidemiology and Infectious Diseases AMS } \\
\text { of Ukraine, Kiev, Ukraine }\end{array}$} \\
\hline A/Luhansk/5192/2011(H1N1) & 2011-03-07 & & EPI_ISL_99895 & \\
\hline $\mathrm{A} /$ Minsk/1131/2011(H1N1) & 2011-02-15 & & EPI_ISL_94707 & Laboratory of Influenza and ILI, Minsk, Belarus \\
\hline A/Estonia/53646/2011( $\left.\mathrm{H}_{1} \mathrm{~N}_{1}\right)$ & 2011-02-01 & & EPI_ISL_94695 & Health Protection Inspectorate, Tallin, Estonia \\
\hline A/Kaunas/988/2011(H1N1) & 2011-02-15 & & EPI_ISL_99909 & Lithuanian AIDS Center Laboratory, Vilnius, Lithuania \\
\hline A/Stockholm/35/2011(H1N1) & 2011-11-22 & & EPI_ISL_100460 & \multirow{2}{*}{$\begin{array}{l}\text { Swedish Institute for Infectious Disease Control, } \\
\text { Solna, Sweden }\end{array}$} \\
\hline A/Stockholm/30/2011( $\mathrm{H} 1 \mathrm{~N} 1)$ & 2011-11-09 & & EPI_ISL_99784 & \\
\hline $\mathrm{A} / \mathrm{G}$ oteborg/1/2011(H1N1) & 2011-04-12 & & EPI_ISL_93766 & \\
\hline $\mathrm{A} / \mathrm{Umea}_{\mathrm{I}} / \mathrm{1} / 2011\left(\mathrm{H}_{1} \mathrm{~N}_{1}\right)$ & 2011-01-28 & & EPI_ISL_90424 & \\
\hline A/Norway/2379/2011(H1N1) & 2011-12-08 & & EPI_ISL_100455 & St. Olavs Hospital HF, Trondheim, Norway \\
\hline A/Slovenia/861/2011( $\left.\mathrm{H}_{1} \mathrm{~N}_{1}\right)$ & 2011-02-05 & & EPI_ISL_95550 & \multirow{2}{*}{ National Institute of Public Health, Ljubljana, Slovenia } \\
\hline A/Slovenia/1552/2011(H1N1) & 2011-04-30 & & EPI_ISL_95564 & \\
\hline A/Kastamonu/TR-45/2011(H1N1) & 2011-02-12 & & EPI_ISL_95555 & $\begin{array}{l}\text { Refik Saydam National Public Health Agency, Ankara, } \\
\text { Turkey }\end{array}$ \\
\hline $\mathrm{A} /$ Iceland/3/2011(H1N1) & 2011-01-10 & & EPI_ISL_99914 & \multirow{2}{*}{ Landspitali - University Hospital, Reykjavik, Iceland } \\
\hline $\mathrm{A} /$ Iceland/59/2011(H1N1) & $2011-03-24$ & & EPI_ISL_99924 & \\
\hline $\mathrm{A} /$ Trieste/11/2011(H1N1) & 2011-01-11 & & EPI_ISL_90758 & Istituto Superiore di Sanità, Rome, Italy \\
\hline A/Grenoble/1772/2011(H1N1) & 2011-09-21 & & EPI_ISL_103048 & CRR virus Influenza region Sud, Cedex, France \\
\hline A/Vermont/16/2011(H1N1) & $2011-12-22$ & & EPI_ISL_103212 & $\begin{array}{l}\text { Vermont Department of Health Laboratory, Burlington, } \\
\text { United States }\end{array}$ \\
\hline A/Florida/27/2011(H1N1) & $2011-10-30$ & & EPI_ISL_99811 & $\begin{array}{l}\text { Florida Department of Health-Tampa Bureau of } \\
\text { Laboratories, Tampa, United States }\end{array}$ \\
\hline $\mathrm{A} /$ Christchurch/16/2010(H1N1) & $2010-07-12$ & & EPI_ISL_79722 & $\begin{array}{l}\text { WHO Collaborating Centre for Reference and Research } \\
\text { on Influenza, Victoria, Australia }\end{array}$ \\
\hline A/Singapore/GP4670/2010( $\left.\mathrm{H}_{1} \mathrm{~N}_{1}\right)$ & $2010-12-30$ & CYo91676 & & National Public Health Laboratory, Singapore, \\
\hline A/Song Khla/270/2011(H1N1) & 2011-09-12 & & EPI_ISL_99814 & $\begin{array}{l}\text { WHO National Influenza Centre, National Institute of } \\
\text { Medical Research (NIMR), Nonthaburi, Thailand }\end{array}$ \\
\hline A/Hong Kong/3934/2011(H1N1) & $2011-03-29$ & & EPI_ISL_93746 & Government Virus Unit, Kowloon, Hong Kong \\
\hline $\mathrm{A} /$ Johannesburg/150/2011(H1N1) & 2011-07-10 & & EPI_ISL_99903 & $\begin{array}{l}\text { National Institute for Communicable Disease, } \\
\text { Sandringham-Johannesburg, South Africa }\end{array}$ \\
\hline A/Ghana/763/2011(H1N1) & $2011-05-13$ & & EPI_ISL_94709 & University of Ghana, Accra, Ghana \\
\hline $\mathrm{A} /$ Cameroon/LEID/o7/11/1870/2011(H1N1) & 2011-07-07 & & EPI_ISL_99899 & Centre Pasteur du Cameroun, Yaoundé, Cameroon \\
\hline $\mathrm{A} /$ Cameroon/LEID/01/11/1450/2011(H1N1) & 2011-01-19 & & EPI_ISL_99900 & Centre Pasteur du Cameroun, Yaoundé, Cameroon \\
\hline A/Abobo/GR753/2011(H1N1) & 2011-09-12 & & EPI_ISL_103049 & Pasteur Institut of Côte d'Ivoire, Abidjan, Cote d'Ivoire \\
\hline A/Madagascar/9252/2011(H1N1) & 2011-08-10 & & EPI_ISL_99934 & $\begin{array}{l}\text { Institut Pasteur de Madagascar, Antananarivo, } \\
\text { Madagascar }\end{array}$ \\
\hline
\end{tabular}


circulating in another country, that could affect severity of disease in these countries. Regardless of the reasons behind the current situation, early admission, prompt diagnosis and early antiviral treatment improve the outcome of patients infected with influenza $A\left(\mathrm{H}_{1} \mathrm{~N}_{1}\right)$ pdmog.

\section{Acknowledgements}

The authors wish to acknowledge epidemiologists from the Regional Public Health Authorities, virologists from regional laboratories as well as hospital physicians for providing reports related to ICU influenza patients. Virological testing as well as genome sequencing and subsequent phylogenetic analysis of influenza virus strains were partly supported by research grant IGA NT 12493-3/2011. We acknowledge the authors, originating and submitting laboratories of the sequences from GISAID's EpiFlu Database and NCBI's Influenza Virus Resource database. All the sequence data are available through the GISAID and NCBI websites www.gisaid.org and http://www.ncbi.nlm.nih.gov/genomes/FLU/.

\section{Conflict of interest}

None declared.

\section{Authors' contributions}

JK wrote the manuscript and is responsible for analysis of data from epidemiological surveillance. $\mathrm{MH}$ and $\mathrm{HJ}$ are responsible for analysis of data from virological surveillance, both contributed to the manuscript. AN did the genome sequencing and phylogenetic analysis and contributed to the manuscript. IP run the hospital ICU database and contributed to the manuscript.

\section{References}

1. Kyncl J, Paget WJ, Havlickova M, Kriz B. Harmonisation of the acute respiratory infection reporting system in th Czech Republic with the European community networks. Euro Surveill. 2005;10(3):pii=525. Available from: http:// www.eurosurveillance.org/ViewArticle.aspx?Articleld $=525$ PMid:15827371

2. European Union. Commission Decision of 28 April 2008 amending Decision 2002/253/EC laying down case definitions for reporting communicable diseases to the Community network under Decision No 2119/98/EC of the European Parliament and of the Council. Official Journal of the European Union, 2008, L 159, 64-65.

3. European Centre for Disease Prevention and Control (ECDC) Weekly influenza surveillance overview. Stockholm: ECDC; 18 Jan 2013. Available from: http://www.ecdc.europa.eu/ en/publications/Publications/Forms/ECDC_DispForm. aspx?ID=1038

4. World Health Organization, Regional Office for Europe (WHO/ Europe). Large variation in influenza activity across the WHO European Region. EuroFlu - weekly electronic bulletin. 2013;471. Copenhagen: WHO/Europe; Jan 2013. Available from: http://www.euroflu.org/cgi-files/bulletin_v2.cgi

5. Chowell G, Bertozzi SM, Colchero MA, Lopez-Gatell H, AlpucheAranda $C$, Hernandez $M$, et al. Severe respiratory disease concurrent with the circulation of $\mathrm{H}_{1} \mathrm{~N}_{1}$ influenza. N Engl I Med. 2009;361(7):674-9. http://dx.doi.org/10.1056/NEJMoa0904023 PMid:19564633

6. Lee N, Wong CK, Chan PK, Chan MC, Wong RY, Lun SW, et al. Cytokine response patterns in severe pandemic $2009 \mathrm{H}_{1} \mathrm{~N}_{1}$ and seasonal influenza among hospitalized adults. PLoS One. 2011;6(10):e26050 http://dx.doi.org/10.1371/journal. pone.0026050PMid:22022504 PMCid:3192778

7. Tumpey TM, Belser JA. Resurrected pandemic influenza viruses. Annu Rev Microbiol. 2009;63:79-98. http://dx.doi. org/10.1146/annurev.micro.091208.073359 PMid:19385726
8. Centers for Disease Control and Prevention (CDC). Early Estimates of Seasonal Influenza Vaccine Effectiveness United States, January 2013. MMWR Morb Mortal Wkly Rep. 2013;62:32-5. PMid:23325354

9. Felsenstein J. PHYLIP (Phylogeny Inference Package) version 3.6. Distributed by the author. Seattle: Department of Genome Sciences, University of Washington; 2004. Available from: http://evolution.genetics.washington.edu/phylip.html 